\title{
Biologinių produktų poveikis ekologinių žieminių kviečių sẻklai
}

Jolanta Sinkevičienè,

Juozas Pekarskas,

Aurimas Krasauskas

Aleksandro Stulginskio universitetas,

Studentug. 11,

LT-53361 Akademija, Kauno r.

El.paštas jolanta.sinkeviciene@asu.lt
Biologinių produktų itakos ekologiškų žieminių kviečių (Triticum aestivum L.) sèklos dygimo energijai, daigumui ir užterštumui mikroskopiniais grybais tyrimai atlikti 2005 ir 2008 m. Aleksandro Stulginskio universiteto Agroekologijos centro bei Agronomijos fakulteto Biologijos ir augalų biotechnologijos instituto mokslinėse laboratorijose. Biologiniais produktais apdorojus žieminių kviečiu sèklą, didèjo sèklos dygimo energija ir daigumas. Dèl Biokal 2 poveikio žieminių kviečių sẻkloje nustatytas mažiausias mikroskopinių grybų kolonijų skaičius. Kviečių užterštumą Fusarium, Drechlera ir Alternaria genčių grybais efektyviausiai sumažino biojodis. Biologiniai produktai Biokal 2, Penergetic-p šaknims patikimai slopino sèklos užterštumą Drechlera spp., tačiau jie buvo neefektyvūs mažinant sèklos užteršimą Fusarium spp. grybais. Drègno filtro popieriaus rulonų metodu kviečių daigus koleoptilèse nuo pašaknio pažeidimų patikimai saugojo Biokal 2, šaknų - Biokal 2 ir Penergetic-p šaknims. Kviečių sèklos pažeidimus iš tirtų produktų efektyviausiai mažino biojodis.

Raktažodžiai: ekologinis ūkininkavimas, kviečiai, dygimo energija, daigumas, tarša mikroskopiniais grybais

\section{IVADAS}

Svarbiausios sèklinès medžiagos kokybės rodikliai yra švarumas, daigumas ir jos sanitarinè būklè. Mikroskopiniai grybai turi didelę reikšmę miglinių javų sèklos kokybei. Susidarius palankioms sąlygoms, per sèklą plintantys Fusarium, Penicillium, Aspergillus, Mucor genčių grybai gali sumažinti sèklos dygimo energiją ir daigumą (Ruza et al., 2003), Alternaria, Aspergillus, Rhizopus spp. grybai - sèklų gyvybingumą, susilpninti augalo šaknų sistemą (Lacey et al., 1991), dygstant užterštoms Alternaria grybais sèkloms, jie gali pakenkti augantiems daigams (Thomma, 2003). Kai kurie mikroskopiniai grybai sèklai gali padaryti ir netiesioginę žalą - lemti jos cheminès sudèties pasikeitimus, sukelti nepageidaujamą kvapą, spalvą, deformuoti sèklos paviršių (Christensen, 1987; Schmidt, 1991). Laikant grūdus drègnose ir nevédinamose patalpose dauguma sèklose esančių Fusarium, Aspergillus, Penicillium, Alternaria genčių grybų išskiria toksinus, užteršia juos toksiškais antriniais metabolitais, kurie menkina grūdų kokybę ar net visiškai juos sugadina (Schachermayer, Fried, 2000). Norint išvengti labai pavojingų mikroskopinių grybų paplitimo ir jų veiklos produktų grūduose ir sèklinejje medžiagoje, svarbu žinoti mikromicetų rūšinę sudètí, kuri leidžia pagrịsti atitinkamas profilaktines ir kontrolès priemones (Lõiveke, 2004).

Kontroliuojant patogeninių mikroorganizmų plitimą yra sukurtos efektyvios cheminès priemonès - beicai, kurie išlieka kaip viena plačiausiai naudojamų priemonių, mažinančių su sẻkla plintančių grybinių ligų daromą žalą. Lietuvoje, kaip ir kitose Europos Sąungos šalyse, daugeja ekologinių ūkių. Pagal Europos Sąjungos EEC 2092/91 
direktyvas, ekologiniuose ūkiuose produkcija turi būti užauginama nenaudojant cheminių augalų apsaugos produktų, įskaitant ir priešsejjinị sẻklų apdorojimą. Todèl šiems ūkiams skirtos sèklos turi būti itin geros kokybès, sveikos, neužkrèstos patogeniniais mikroorganizmais, o joms apdoroti naudojami tik biologiniai produktai (Van der Zeijden, 2003). Kaip alternatyva beicavimui, javų sèklai apdoroti naudojami biologiniai produktai (Sliesaravičius et al., 2006; Pekarskas ir kt., 2007). Lietuvoje atliktų tyrimų duomenimis, biologiniai produktai, skirti augalams purkšti vegetacijos metu, gali būti sèkmingai naudojami ir prieš sejją apveliant javų sẻklas (Sliesaravičius ir kt., 2006). Biologiniai produktai ne tik padidina sèklų dygimo energiją ir daigumą, bet gali sumažinti ir sèklu užterštumą tam tikru genčiu mikroskopiniais grybais (Pekarskas ir kt., 2007). Literatūroje randama duomenų apie efektyvų priešsejjinị ekologiškų žieminių kviečių ir miežių sèklos paruošimą sèjai (Pekarskas, Sliesaravičius, 2007), apie teigiamą biojodžio poveikị mažinant žieminių kviečių užterštumą Fusarium genties grybais (Gaurilčikienè ir kt., 2008), daržovių sèklų apdorojimą biologiniais produktais, kurie mažina sèklų mikrobiologinį užterštumą, didina sẻklų dygimo energiją, teigiamai veikia daigų augimą ir vystymąsi (Survilienè, 2007).

Norint, kad biologiniai produktai taptų svarbia augalų apsaugos dalimi, reikia rinktis efektyvias ir patikimas augalų apsaugos priemones, darančias teigiamą itaką augalinei produkcijai, ribojančias mikroskopinių grybų plitimą ir vystymąsi. Naujų produktų paieška - perspektyvi mokslinių tyrinejjimų sritis. Natūralūs augalų junginiai, gaunami antrinio metabolizmo metu, yra svarbus naujo tipo farmacijos potencialas. Nepaisant vis dejančio mokslinių tyrinejjimų šioje srityje kiekio, teorinès ir praktinès žinios apie natūralius antigrybinius augalinius junginius augalų ligoms kontroliuoti yra labai menkos (Matos et al., 1999). Biologiniai produktai, ị kurių sudetị ieina pesticidiniai augalai, gali stabdyti Alternaria, Fusarium, Aspergillus, Botrytis genčių grybų vystymąsi ir išplitimą, mažinti ligų žalingumą pasèlyje, sudaryti optimalias augalų augimo sąlygas (El-Assiuty, 2006; Pârvu et al., 2008; Fawzi et al., 2009). Lietuvoje literatūros apie atskirų biologinių produktų poveikio javų sèkla plintančių mikromicetų kontrolei tyrimus randama mažai, biologinių pro- duktuc poveikis tirtas skirtingu laiku, skirtingais parametrais, kai kurie iš parametrų tyrimų metu keitėsi, todèl tarpusavyje palyginti priemonių poveikio efektyvumo neįmanoma.

Šio tyrimo tikslas - esant vienodoms sąlygoms nustatyti skirtingų biologinių produktų poveiki ekologiškų žieminių kviečių sèklos dygimo energijai ir daigumui; naudojant skirtingas tyrimų metodikas išryškinti produktų poveikị su sẻkla plintantiems mikroskopiniams grybams.

\section{TYRIMU METODAI IR SĄLYGOS}

Tyrimai atlikti 2005 ir 2008 m. Aleksandro Stulginskio universiteto Agroekologijos centre ir Agronomijos fakulteto Biologijos ir augalų biotechnologijos instituto mokslineje laboratorijoje.

Tyrimams imta po $200 \mathrm{~g}$ žieminių kviečių sèklos, kuri buvo apdorota sintetiniu beicu Maksim Star 025 FS (fludijoksonilas $18,75 \mathrm{~g} \mathrm{l}^{-1}$ ir ciprokonazolas 6,25 $\mathrm{g} \mathrm{l}^{-1}$ ) norma $-1,0 \mathrm{lt} \mathrm{t}^{-1}$ bei biologiniais produktais Biokal $1\left(10 \mathrm{l} \mathrm{t}^{-1}\right)$, Biokal 2 $\left(10 \mathrm{lt}^{-1}\right)$, biojodis $\left(2 \mathrm{lt}^{-1}\right)$ ir Penergetic-p šaknims $\left(100 \mathrm{ml} \mathrm{t}^{-1}\right)$.

Žieminių kviečių sèklos dygimo energijai ir daigumui nustatyti iš kiekvieno tyrimo varianto buvo imti keturi èminiai po 100 sèklų. Kviečiai buvo daiginti tamsoje, Petri lèkštelèse, ant drègno filtro popieriaus $3-4$ dienas $8-12{ }^{\circ} \mathrm{C}$ temperatūroje, vèliau $-20{ }^{\circ} \mathrm{C}$. Dygimo energija laboratorijoje nustatyta po 3, o daigumas - po 7 parų.

Skirtingų produktų poveikis žieminių kviečių užterštumui mikoskopiniais grybais nustatyti agarizuotų mitybinių terpių metodu (Mathur, Kongsdal, 2003). Mikroskopiniams grybams išskirti buvo naudotos šios terpès: $2005 \mathrm{~m}$. - Čapeko terpè (ČA) su chloramfenikoliu $\left(0,5 \mathrm{~g} \mathrm{l}^{-1}\right)$, 2008 m. - Čapeko-Dokso (ČD). Sterilios terpès buvo išpilstytos $\mathfrak{i}$ sterilias Petri lekkšteles. Petri lekkštelèje ant terpès paviršiaus buvo išdèliota po 10 sèklų. Kiekvieno tyrimų varianto ėminio mikologiniai tyrimai atlikti 4 pakartojimais ėmus po 50 sèklų. Sèklos inkubuotos termostate $23 \pm 2{ }^{\circ} \mathrm{C}$ temperatūroje. Augančios grybų kolonijos identifikuotostos 3, 5 ir 7 jų vystymosi parą. Mikroskopinių grybų pažeistų sèklų skaičius ịvertintas procentais nuo bendro tirto sèklų kiekio. Kolonijos, suformavusios rūšiai būdingus požymius, buvo identifikuotos remiantis J. Leslie, B. Summerell (2006), D. Satton ir kt., (2001) apibūdinimais. 
Mikroskopinių grybų, sudariusių kolonijas, skaičius ( $\mathrm{Ksv} \mathrm{g}^{-1}$ ) viename grame sèklos nustatytas pagal LST EN ISO 7218:2007. Gentinè sudètis nustatyta remiantis J. Leslie, B. Summerell (2006) ir D. Satton ir kt. (2001) apibūdinimais.

Pašaknio ligų patogenų pažeidimai kviečių daigų koleoptilèse, šaknyse ir sèklos užterštumas nustatyti filtro popieriaus rulonų metodu (Dabkevičius, Gaurilčikienė, 2002). Kiekvieno varianto èminio tyrimai atlikti 4 pakartojimais po 50 sèklų.

Biokal 1 yra natūralios kilmès organinè trąša, sudaryta iš $57,0 \%$ vaistažolių, $38,0 \%$ biohumuso ekstrakto, 5,0 \% eterinių aliejų, mikroelementų, natūralios kilmès mineralinių medžiagų. Biokal 1 yra apie $230 \mathrm{mg} \mathrm{l}^{-1}$ azoto, $370 \mathrm{mg} \mathrm{l}^{-1}$ fosforo, $480 \mathrm{mg} \mathrm{l}^{-1}$ kalio, $110 \mathrm{mg} \mathrm{l}^{-1}$ kalcio, $30 \mathrm{mg} \mathrm{l}^{-1}$ magnio, $10 \mathrm{mg} \mathrm{l}^{-1}$ geležies. Be šių medžiagų taip pat yra boro, cinko, vario, mangano, įvairių biologiškai aktyvių medžiagų. Vaistažolių ekstraktas sudarytas iš didžiųjų dilgèlių (Urtica dioica L.), dirvinių asiūklių (Equiseptum arvense L.) ir didžiųjų ugniažolių (Chelidonium majus) (Pekarskas, 2008).

Biokal 2 yra natūralios kilmès organinè trąša, i kurios sudèti įeina $45 \%$ vaistažolių, $40 \%$ biohumuso ir $10 \%$ medžio pelenų ekstraktų bei $5 \%$ eterinių aliejų, mikroelementų, natūralios kilmès mineralinių medžiagų (Pekarskas, 2008).

Penergetic-p šaknims yra augimo aktyvatorius (Pekarskas, 2008).

Biojodis sudarytas iš biohumuso vandeninio ekstrakto, praturtinto biologiškai aktyviu jodu, biotransformatoriais, mikroelementais. Biologiškai aktyvus jodas pasižymi bakteriocidinèmis savybėmis (Sliesaravičius et al., 2006).

Rezultatų statistinè analizè. Duomenų vertinimas atliktas taikant statistinių duomenų apdorojimo paketą SELEKCIJA, naudojant dispersinès analizès ANOVA programą (Tarakanovas, Raudonius, 2003).

\section{TYRIMŲ REZULTATAI IR JŲ APTARIMAS}

Žieminių kviečių sẻklą apvèlus biologiniais produktais, sèklos dygimo energija, palyginti su neapveltomis sèklomis, padidejo (1 lentelè). Dygimo energija po sèklos apdorojimo Biokal 2 ir biojodžiu padidejo 4 , o daigumas - 3 procentiniais vienetais. Iš tirtų produktų cheminio beico Maxim Star ir Penergetic-p šaknims poveikis kviečių dygimo energijai buvo žemiausias. Maxim Star beicuotų žieminių kviečių daigumas, palyginti su neapdorota sẻkla, sumažèjo 1 procentiniu vienetu.

1 lentelè. Biologinių produktų ịtaka žieminių kviečių sèklos dygimo energijai ir daigumui, 2005

Table 1. The effect of biological products on winter wheat seed germination power and germination, 2005

\begin{tabular}{|c|c|c|}
\hline $\begin{array}{l}\text { Apdorojimas } \\
\text { Treatment }\end{array}$ & 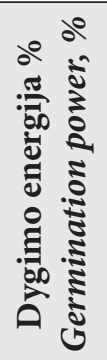 & 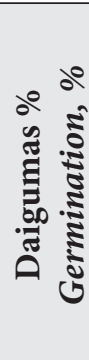 \\
\hline Neapdorotos sèklos / Untreated & 83,0 & 87,0 \\
\hline Maxim Star $11 \mathrm{t}^{-1}$ & 84,0 & 86,0 \\
\hline Biokal $1101 \mathrm{t}^{-1}$ & 85,0 & 88,0 \\
\hline Biokal $210 \mathrm{lt}^{-1}$ & 87,0 & 90,0 \\
\hline Biojodis $2 \mathrm{lt}^{-1}$ & 87,0 & 90,0 \\
\hline $\begin{array}{l}\text { Penergetic-p šaknims } 100 \mathrm{ml} \mathrm{t}^{-1} \\
\text { Penergetic- } p \text { for roots, } 100 \mathrm{ml} \mathrm{t}^{-1}\end{array}$ & 84,0 & 88,0 \\
\hline $\mathrm{LSD}_{05}$ & 2,31 & 2,48 \\
\hline
\end{tabular}

Panašūs kviečių sèklos dygimo energijos ir daigumo dèsningumai gauti atlikus tyrimus ir $2008 \mathrm{~m}$. (2 lentelè). Čia nustatyta žymiai didesnè ekologišku žieminių kviečiu sèklos dygimo energija ir daigumas nei 2005 m. atliktų tyrimų metu. Kviečių sẻklą apvèlus biologiniais produktais, sèklų dygimo energija padidèjo 1,3-2,7 procentiniais vienetais, palyginti su neapveltomis sẻklomis. Labiausiai kviečiu dygimo energiją padidino Penergetic-p šaknims, nors 2005 m. jo efektyvumas buvo mažiausias. Apvèlus kviečių sèklą Penergetic-p šaknims, padidèjo sèklos dygimo energija, palyginti su neapveltais kviečiais, bet negauta žymesnių skirtumų, palyginti su Biokal 1, Biokal 2 ir biojodžiu. Apvèlus žieminių kviečių sèklą Biokal 1, Biokal 2 ir biojodžiu, gautos vienodos sèklos dygimo energijos reikšmès. Tiriant biologinių produktų įtaką sèklos daigumui nustatyta, kad po kviečių sèklos apdorojimo Penergetic-p šaknims gautas toks pats daigumo rezultatas kaip ir neapdorotų kviečių. Analogiški tyrimų rezultatai gauti ir $2005 \mathrm{~m}$. Žieminiams kviečiams apdoroti panaudojus Biokal 1, Biokal 2 ir biojodit, sẻklos daigumas padidejo. Didžiausi daigumai nustatyti po séklos apdorojimo Biokal 2 ir Biokal 1. Lyginant biologinių produktų panaudojimą apveliant žieminių kviečių sẻklas tarpusavyje nustatyta, kad biologiniai 
preparatai neturèjo esminès įtakos žieminių kviečių sèklos dygimo energijai ir daigumui.

2 lentelè. Biologinių produktų ịtaka žieminių kviečių sèklos dygimo energijai ir daigumui, 2008

Table 2. The effect of biological products on winter wheat seed germination power and germination, 2008

\begin{tabular}{|c|c|c|}
\hline $\begin{array}{l}\text { Apdorojimas } \\
\text { Treatment }\end{array}$ & 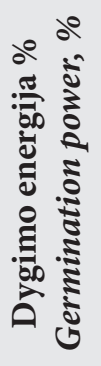 & 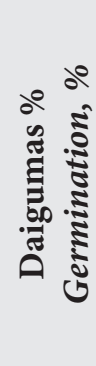 \\
\hline Neapdorotos sèklos / Untreated & 94,0 & 99,0 \\
\hline Biokal $110 \mathrm{lt}^{-1}$ & 95,3 & 99,7 \\
\hline Biokal $2101 \mathrm{t}^{-1}$ & 95,3 & 99,7 \\
\hline Biojodis $2 \mathrm{lt}^{-1}$ & 95,3 & 99,3 \\
\hline $\begin{array}{l}\text { Penergetic-p šaknims } 100 \mathrm{ml} \mathrm{t}^{-1} \\
\text { Penergetic- } p \text { for roots, } 100 \mathrm{ml} \mathrm{t}^{-1}\end{array}$ & 96,7 & 99,0 \\
\hline $\mathrm{LSD}_{05}$ & 1,58 & 1,68 \\
\hline
\end{tabular}

2005 m. nustačius biologiniais produktais neapdorotų žieminių kviečių užterštumą mikroskopiniais grybais, paaiškejo, kad sèklos tarša siekè $9,0 \times 10^{3} \mathrm{Ksv} \mathrm{g}^{-1}$ (3 lentelè). Mažiausias mikroskopinių grybų kolonijų skaičius, palyginti su neapdorotais kviečiais, nustatytas cheminiu beicu Maxim
Star apdorotoje žieminių kviečių sẻkloje. Visi tirti biologiniai produktai mažino kviečių taršą mikroskopiniais grybais. Iš tirtų produktų Biokal 2 efektyviausiai sumažino kviečių sèklos taršą. I Biokal 1 ir Biokal 2 sudèti įeina 57 ir $45 \%$ skirtingų vaistažolių ekstraktų, kurių sudetyje esantis Chelidonium majus L. (Papaveraceae) turi stiprių antigrybinių savybių prieš kai kurias Fusarium spp. (Matos et al., 1999) ir Botrytis spp. grybų rūšis (Jiratko, Vesela, 1992). Mokslininkai teigia, kad nors C. majus alkaloidas chelidoninas F. culmorum ir F. graminearum grybienoms augti ir vystytis jokio poveikio neturi, tačiau aktyviai slopina F. oxysporum, F. solanum augimą (Matos et al., 1999). It Biokal 1 sudètị ịeinantis Equisetum arvense L. (Equisetaceae) eterinis aliejus turi stiprų antigrybini poveiki prieš grybus Aspergillus niger (Radulovic et al., 2006). Penergetic-p šaknims silpniausiai sumažino mikroskopinių grybų kolonijų skaičių, kuris, palyginti su kitais tyrimų variantais, buvo didžiausias $-7,3 \times 10^{3} \mathrm{Ksv} \mathrm{g}^{-1}$.

Tyrimų metu iš neapdorotos žieminių kviečių sèklos buvo išskirti Aspergillus, Fusarium, Penicillium genčiu grybai (3 lentelè). Vieni šiu grybų lengvai pasiekia sèklos endospermą (Fusarium), kiti geriau vystosi sèklos apmirusiuose audiniuose (Aspergillus, Penicillium), tačiau neretai pažeidžia ir grūdus, be to, jie žinomi kaip toksiškų antrinių metabolitų producentai (Lugauskas ir kt., 2004). Tiriant mikroskopinių grybų rūšiu sudètị daugiausia

3 lentelè. Biologinių produktų ịtaka žieminių kviečių sẻklos užterštumui mikroskopiniais grybais, 2005

Table 3. The effect of biological products on winter wheat seed infection, 2005

\begin{tabular}{|c|c|c|c|}
\hline $\begin{array}{l}\text { Apdorojimas } \\
\text { Treatment }\end{array}$ & $\begin{array}{c}\text { Sẻklos užterštumas } \\
\text { Contamination of } \\
\text { seeds } \\
\text { Ksv g }^{-1}\end{array}$ & $\begin{array}{c}\text { Išskirtų grybų } \\
\text { rūšių skaičius } \\
\text { Number of isolated } \\
\text { fungi species }\end{array}$ & $\begin{array}{l}\text { Dominuojančios grybų rūšys } \\
\text { Dominant fungal species }\end{array}$ \\
\hline $\begin{array}{c}\text { Neapdorotos séklos } \\
\text { Untreated }\end{array}$ & $9,0 \times 10^{3}$ & 4 & $\begin{array}{l}\text { Aspergillus oryzae (Ahlb.) Cohn } \\
\text { Fusarium nivale Ces. ex Sacc. }\end{array}$ \\
\hline Maxim Star $11 \mathrm{t}^{-1}$ & $2,8 \times 10^{3}$ & 3 & $\begin{array}{l}\text { Aspergillus flavus Link } \\
\text { Penicillium verrucosum }\end{array}$ \\
\hline Biokal $210 \mathrm{lt}^{-1}$ & $4,2 \times 10^{3}$ & 3 & $\begin{array}{l}\text { Fusarium poae (Peck) Wollenw. } \\
\text { Aspergillus oryzae (Ahlb.) Cohn } \\
\text { Penicillium expansum Link }\end{array}$ \\
\hline Biokal $110 \mathrm{lt}^{-1}$ & $6,1 \times 10^{3}$ & 3 & $\begin{array}{c}\text { Fusarium poae (Peck) Wollenw. } \\
\text { Mycelia sterilia }\end{array}$ \\
\hline Biojodis $2 \mathrm{lt}^{-1}$ & $6,0 \times 10^{3}$ & 3 & $\begin{array}{c}\text { Aspergillus oryzae (Ahlb.) Cohn } \\
\text { Aspergillus flavus Link }\end{array}$ \\
\hline $\begin{array}{l}\text { Penergetic-p šaknims } 100 \mathrm{ml} \mathrm{t}^{-1} \\
\text { Penergetic- } p \text { for roots, } 100 \mathrm{ml} \mathrm{t} t^{-1}\end{array}$ & $7,3 \times 10^{3}$ & 7 & $\begin{array}{c}\text { Aspergillus oryzae (Ahlb.) Cohn } \\
\text { Penicillium expansum Link }\end{array}$ \\
\hline $\mathrm{LSD}_{05}$ & 1,58 & & \\
\hline
\end{tabular}


izoliatu priskirta Aspergillus oryzae (Ahlb.) Cohn, Aspergillus flavus Link., Penicillium expansum Link. rūšių mikroskopiniams grybams. Tirtų biologinių produktų poveikis mikroskopinių grybų rūšinei sudéčiai buvo panašus - visuose tyrimų variantuose buvo išskirta po 3 grybų rūšis, tik Penergetic-p šaknims apdorotoje kviečių sèkloje buvo išskirtas gausiausias grybų rūšių skaičius.

2008 m. agarizuotų mitybinių terpių metodu buvo nustatytas žieminių kviečių užterštumas mikroskopiniais grybais. Tyrimo metu neapdorota žieminių kviečių sèkla buvo užteršta Fusarium spp. (5,5 \%), Drechlera spp. (4,0 \%), Alternaria spp. (40,5\%) ir Penicillium spp. (17,5 \%) grybais (4 lentelè). Kviečiai taip pat buvo užteršti rečiau sutinkamomis ir tyrime kitiems grybams priskirtoms gentims: Cladosporium, Aspergillus, Rhizopus, Mucor, Mycelia sterilia.

Didžiausiu efektyvumu laboratorijoje išsiskyrè biojodis, kurio biologinis efektyvumas mažinant kviečių sèklos užterštumą patogeniniais Fusarium genties grybais sieke 81,8 \%, Drechlera - $100 \%$ ir Alternaria - 30,9 \%. Galime daryti prielaidą, kad toki grybų sumažèjimą galèjo lemti biojodžio sudètyje esantis biologiškai aktyvus jodas, kuris pasižymi antimikrobinèmis savybèmis. Tačiau biojodis neturëjo teigiamo poveikio mažinant kviečių sèklos taršą Penicillium genties grybais, nors, I. Gaurilčikienès ir kt., (2008) duomenimis, laboratorinèmis sąlygomis kviečiu sęklos, apdorotos biojodžiu $\left(2 \mathrm{t} \mathrm{t}^{-1}\right)$, Penicillium spp. grybais buvo užterštos mažiau nei neapdorotos.

Tyrimo metu nustatyta, kad Biokal 1 patikimai sumažino Drechlera ir Penicillium genčių grybų kiekị žieminių kviečių sèkloje ir jo biologiniai efektyvumai atitinkamai sudare 80,0 ir $45,7 \%$.
Biologiniai produktai Biokal 2 ir Penergeticp šaknims patikimai sumažino séklos užterštumą Drechlera spp. patogenais, tačiau šie produktai buvo neefektyvūs mažinant sẻklos užteršimą Fusarium spp. grybais. Kviečių užteršimas Fusarium spp. grybais, palyginti su neapdorota sèkla, dèl Biokal 2 poveikio padidèjo 2,5 \%, Penergetic-p šaknims - 1,0 \%. Nuo Alternaria spp. grybų šių biologinių produktų antigrybinis poveikis laboratorinèmis sąlygomis neišryškejjo.

Atliekant tyrimą buvo svarbu įvertinti biologiniu produktų poveiki pašaknio ligu patogenų pažeidimams žieminių kviečių daigų koleoptilèse, šaknyse ir nustatyti sẻklos užterštumą mikroskopiniais grybais drégno filtro popieriaus rulonų metodu. Kviečiai yra jautrūs pašaknio puviniams. Kviečių pašaknio puvinio sukẻlejų ìvairių štamų patogeniškumas yra skirtingas. Tos pačios grybų rūšies vienas štamas būna stipriau, kitas silpniau patogeniškas, be to, grybų rūšinè sudètis priklausomai nuo įvairių ekologinių veiksnių kinta (Knudsen et al., 1995). Pašaknio puvinius žiemkenčiuose gali sukelti Bipolaris sorokiniana (Sacc. In Sorok) Shoem., Drechslera sorokiniana (Sacc.) Subram. \& Jain.), Fusarium avenaceum (Fr.: Fr.) Sacc., F. culmorum (Wm. G. Sm.) Sacc., F. graminearum Schwabe (Dabkevičius et al., 2002).

Biologiniais produktais neapdorotu žieminių kviečių daigai ir šaknys pašaknio ligomis buvo stipriai pažeisti, nors vidutinis pašaknio ligų išsivystymas ant daigu koleoptilių buvo nedidelis ir sudarè 1,14\% (5 lentelè). Panaudojus Biokal 2, Penergetic-p šaknims ir biojodžio, kviečių daigu koleoptilių pažeidimų sumažèjo nuo 9,0 iki 19,0 procentinių vienetų. Dèl Biokal 2 poveikio pašaknio ligų intensyvumas sumažejo efektyviausiai.

4 lentelè. Biologinių produktų itaka žieminių kviečių sẻklos užterštumui mikroskopiniais grybais, 2008

Table 4. The effect of biological products on winter wheat seed infection with fungi, 2008

\begin{tabular}{|c|c|c|c|c|c|c|c|c|}
\hline \multirow{3}{*}{$\begin{array}{l}\text { Apdorojimas } \\
\text { Treatment }\end{array}$} & \multicolumn{8}{|c|}{ Sėklos užterštumas grybais \% / Seed affected by fungi, \% } \\
\hline & \multicolumn{2}{|c|}{ Fusarium spp. } & \multicolumn{2}{|c|}{ Drechslera spp. } & \multicolumn{2}{|c|}{ Alternaria spp. } & \multicolumn{2}{|c|}{ Penicillium spp. } \\
\hline & 1 & 2 & 1 & 2 & 1 & 2 & 1 & 2 \\
\hline Neapdorotos sèklos / Untreated & 5,5 & - & 4,0 & - & 40,5 & - & 17,5 & - \\
\hline Biokal $110 \mathrm{lt}^{-1}$ & 4,0 & 27,2 & $0,8^{*}$ & 80,0 & 38,0 & 6,2 & $9,5^{*}$ & 45,7 \\
\hline Biokal $210 \mathrm{lt}^{-1}$ & 8,0 & 0 & $0,5^{\star}$ & 87,5 & 40,5 & 0 & 17,0 & 2,9 \\
\hline Biojodis $2 \mathrm{lt}^{-1}$ & $1,0^{*}$ & 81,8 & $0^{*}$ & 100 & $28,0^{*}$ & 30,9 & 18,5 & 0 \\
\hline $\begin{array}{l}\text { Penergetic-p šaknims } 100 \mathrm{ml} \mathrm{t}^{-1} \\
\text { Penergetic- } p \text { for roots, } 100 \mathrm{ml} \mathrm{t}^{-1}\end{array}$ & 6,5 & 0 & $0^{*}$ & 100 & 41,5 & 0 & 11,0 & 37,1 \\
\hline $\mathrm{LSD}_{0_{5}}$ & 2,82 & & 2,25 & & 8,76 & & 5,62 & \\
\hline
\end{tabular}

1 - užteršta \% / Incidence, \%; 2 - biologinis efektyvumas / Biological efficiency, $\%$; ${ }^{*}$ - iš esmès skyresi nuo kontrolinio varianto 0,05 tikimybès lygiu / significantly different from the control with the level of probability at 0.05 . 
5 lentelè. Biologinių produktų ịtaka žieminių kviečių daigų šaknų ir sẻklų ligotumui pašaknio ligomis, 2008 Table 5. The effect of biological products on winter wheat hypocotyls, roots and seeds against root rots in 2008

\begin{tabular}{|c|c|c|c|c|c|c|c|c|}
\hline \multirow{2}{*}{$\begin{array}{l}\text { Apdorojimas } \\
\text { Treatment }\end{array}$} & \multicolumn{3}{|c|}{ Koleoptilès / Hypocotyls } & \multicolumn{3}{|c|}{ Šaknys / Roots } & \multicolumn{2}{|c|}{ Sèklos / Seeds } \\
\hline & 1 & 2 & 3 & 1 & 2 & 3 & 1 & 3 \\
\hline Neapdorotos sėklos / Untreated & 36,0 & 1,14 & - & 36,0 & 1,12 & - & 39,0 & - \\
\hline Biokal $1101 \mathrm{t}^{-1}$ & 30,0 & $0,82^{*}$ & 28,1 & 26,0 & $0,52^{*}$ & 53,6 & 34,0 & 12,8 \\
\hline Biokal $2101 \mathrm{t}^{-1}$ & $17,0^{*}$ & $0,40^{*}$ & 64,9 & $10,0^{*}$ & $0,20^{*}$ & 82,1 & 32,0 & 17,9 \\
\hline Biojodis $2 \mathrm{lt}^{-1}$ & $27,0^{*}$ & $0,74^{*}$ & 35,1 & $19,0^{*}$ & $0,38^{\star}$ & 66,1 & 26,0 & 33,3 \\
\hline $\begin{array}{l}\text { Penergetic-p šaknims } 100 \mathrm{ml} \mathrm{t}^{-1} \\
\text { Penergetic- } p \text { for roots, } 100 \mathrm{ml} \mathrm{t} \mathrm{t}^{-1}\end{array}$ & $21,0^{*}$ & $0,78^{*}$ & 31,6 & $10,0^{*}$ & $0,30^{*}$ & 73,2 & 31,0 & 20,5 \\
\hline $\mathrm{LSD}_{05}$ & 8,82 & 0,20 & & 11,64 & 0,10 & & 8,30 & \\
\hline
\end{tabular}

1 - pažeista \% / Damaged, \%; 2 - ligų intensyvumas \% / Severity index, \%; 3 - biologinis efektyvumas / Biological efficiency, $\%$; ${ }^{*}$ iš esmès skyrèsi nuo kontrolinio varianto 0,05 tikimybès lygiu / significantly different from the control with the level of probability at 0.05 .

Efektyviausiai iš tirtujų produktų pašaknio patogenų pažeidimus šaknyse apribojo Biokal 2 ir Penergetic-p šaknims. Jie pašaknyje plitusių patogenų pažeidimų kiekį, palyginti su neapdorota sèkla, sumažino 26 procentiniais vienetais.

Biologinių produktų poveikis patogeniniams grybams žieminių kviečių sèkloje buvo silpnas. Iš tirtųju produktų biojodis efektyviausiai apsaugojo kviečių sẻklą filtro popieriaus rulonuose, panašūs sumažejimo dèsningumai šiuo metodu tirto produkto buvo gauti ir I. Gaurilčikienès ir kt. (2008).

\section{IŠVADOS}

1. Biologiniais produktais apdorojus ekologišką žieminių kviečių sèklą, didejo jos dygimo energija ir daigumas.

2. Dèl Biokal $210 \mathrm{lt} \mathrm{t}^{-1}$ poveikio ant žieminių kviečių sèklos nustatytas mažiausias mikroskopinių grybų kolonijų skaičius.

3. Žieminių kviečių sẻklą nuo patogeninių Fusarium, Drechlera ir Alternaria genčių grybų efektyviausiai saugojo biojodis $2 \mathrm{l} \mathrm{t}^{-1}$, nors Biokal 2 $10 \mathrm{lt}^{-1}$ ir Penergetic-p šaknims $100 \mathrm{ml} \mathrm{t}^{-1}$ taip pat patikimai sumažino sẻklos užterštumą Drechlera genčių grybais, tačiau neefektyviai mažino sèklos užteršimą Fusarium spp. grybais.

4. Žieminių kviečių koleoptilių pažeidimai patogeniniais grybais kviečiuose patikimai sumažejo dèl Biokal $210 \mathrm{l} \mathrm{t}^{-1}$, šaknų - Biokal $210 \mathrm{l} \mathrm{t}^{-1} \mathrm{ir}$ Penergetic-p šaknims $100 \mathrm{ml} \mathrm{t}^{-1}$ poveikio.

Gauta 20150209 Priimta 20150617

\section{LITERATŪRA}

1. Christensen C. M. 1987. Field and storage fungi. In: L. R. Van Nostrand Reinhold Beuchat (ed.). Food and Beverage Mycology. New York. P. 211-232.

2 Dabkevičius Z., Gaurilčikienė I., Semaškienè R. 2002. Varpinių javų ligos. Iš: J. Šurkus, I. Gaurilčikienè (sud.). Žemés ūkio augalų kenkejai, ligos ir ju apskaita. P. 80-134.

3. El-Assiuty E. M., Bekheet F. M., Fahny Z. M., Ismael A. M., El-Alfy T. S. M. 2006. Potentiality of some isolated compounds from Halfa Barr (Cymbopogon proximus Stapf.) against the toxigenic fungi Fusarium verticillioides and Aspergillus flavus. Egyptian Journal of Phytopathology. Vol. 34(2). P. 75-84.

4. Fawzi E. M., Khalil A. A., Afifi A. F. 2009. Antifungal effect of some plant extracts on Alternaria alternata and Fusarium oxsysporum. African Journal of Biotechnology. Vol. 8(11). P. 2590-2597.

5. Gaurilčikienè I., Supronienė S., Ronis A. 2008. The impact of the biological agent biojodis on the incidence of pathogenic fungi in winter wheat and spring barley. Žemdirbystè-Agriculture. Vol. 95(3). P. 406-414.

6. Jiratko J., Vesela G. 1992. Effect of plant extracts on the growth of plant pathogenic fungi in vitro. Ochrana Rostlin. Vol. 28(4). P. 241-282.

7. Knudsen M. B., Hockenhull J., Jensen D. F. 1995. Biocontrol of seedling diseases of barely and wheat caused by Fusarium culmorum and Bipolaris sorokiniana: effects of selected fungal antagonists on growth and yield components. Plant Pathology. Vol. 44. P. 467-477.

8. Lacey J., Magan N. 1991. Fungi in cereal grains: their occurance and water and temperature relationships. In: J. Chelkowski. Cereal Grain. Mycotoxins. Fungi and Quality in Drying and Storage. Amsterdam. P. 77-118. 
9. Leslie J. F., Summerell B. A. 2006. The Fusarium Laboratory Manual. Iowa, USA: Blackwell Publishing. $388 \mathrm{p}$.

10. Lōiveke H., Ilumäe E., Laitamm H. 2004. Microfungi in grain and grain feeds and their potential to toxicity. Agronomy Research. Vol. 2(2). P. 195-205.

11. LST EN ISO 7218:2007. Maisto ir pašaru mikrobiologija. Mikrobiologinių tyrimų bendrieji reikalavimai ir rekomendacijos (tapatus ISO 7218:2007). Vilnius: Lietuvos standartizacijos departamentas, 2008.

12. Lugauskas A., Krasauskas A., Repečkienè J. 2004. Ekologiniai veiksniai, lemiantys mikromicetų paplitimą ant javų grūdų ir sojų sèklų. Ekologija. Nr. 2. P. 21-32.

13. Mathur S. B., Kongsdal O. 2003. Common Laboratory Seed Health Testing Methods for Detecting Fungi. Copenhagen. $425 \mathrm{p}$.

14. Matos O. C., Baeta J., Silva M. J., Pinto Ricardo C. P. 1999. Sensitivity of Fusarium strains to Chelidonium majus L. extracts. Journal of Ethnopharmacology. Vol. 66. P. 151-158.

15. Pârvu M., Pârvu A. E., Craciun C., BarbuTudoran L., Tamas M. 2008. Antifungal activities of Chelidonium majus extract on Botrytis cinerea in vitro and ultrastructural changes in its conidia. Journal of Phytopathology. Vol. 156. P. 550-552.

16. Pekarskas J., Sliesaravičius A. 2007. Effect of different biological agents on different varieties of wheat yield and their quality. Rural Development 2007: Proceedings of the Third International Scientific Conference. Vol. 3(2). P. 207-210.

17. Pekarskas J., Krasauskas A., Šileikienè D. 2007. Employment of biological preparation "Biokal" for pickling of winter wheat grain. Botanica Lithuanica. Vol. 13(4). P. 287-291.

18. Pekarskas J. 2008. Tręšimas ekologinès gamybos ükiuose. Kaunas, 189 p.

19. Radulovic N., Stojanovic G., Radosav P. 2006. Composition and antimicrobial activity of Equisetum arvense L. essential oil. Phytotherapy Research. Vol. 20(1). P. 85-88.

20. Ruza A., Linina A., Gaile Z., Bankina B. 2003. Possibilities of long-term storage of cereal seeds. Vagos. Vol. 64(17). P. 72-76.

21. Satton D., Fotergill A., Rimaldi M. 2001. Opredelitel patogennykh i uslovno patogennykh gribov. Moskva. $451 \mathrm{~s}$.

22. Schachermayer G., Fried M. P. 2000. Problemkreis Fusarien und ihre Mykotoxine. AGRAR Forschung. Vol. 7(6). P. 252-257.

23. Schmidt H. L. 1991. Cereal grain structure and the way in which fungi colonize kernel cells. In: J. Chelkowski. Cereal Grain. Mycotoxins. Fungi and Quality in Drying and Storage. P. 1-22.

24. Sliesaravičius A., Pekarskas J., Rutkovienè V., Baranauskis K. 2006. Grain yield and disease resistance of winter cereal varieties and application of biologi- cal agent in organic agriculture. Agronomy Research. Vol. 4. P. 371-378.

25. Survilienè E., Duchovskienè L. 2008. Kenksmingu organizmų tyrimų aktualijos daržininkystèje. Sodininkystè ir daržininkystė. T. 27. Nr. 3. P. 313-325.

26. Tarakanovas P., Raudonius S. 2003. Agronominiu tyrimu duomenu statistine analize taikant kompiuterines programas ANOVA, STAT, SPLIT-PLOT iš paketo SELEKCIJA ir IRRISTAT. Akademija. 57 p.

27. Thomma B. P. H. J. 2003. Alternaria spp.: From general saprophyte to specific parasite. Molecular Plant Pathology. Vol. 4(4). P. 225-236.

28. Van der Zeijden D. 2003. The Economics of Bejo's Organic Seed Programme. Organic Seed Production and Plant Breeding - Strategies, Problems and Perspectives: Proceedings of ECO-PB 1st International Symposium. Berlin, Germany. P. 55-58.

\section{Jolanta Sinkevičienė, Juozas Pekarskas, Aurimas Krasauskas}

\section{INFLUENCE OF BIOLOGICAL PRODUCTS ON ORGANIC WINTER WHEAT SEED}

Sum mary

The influence of biological products on organic winter wheat germination energy, germination and contamination with microscopic fungi was investigated within the research. Winter wheat 'Sirvinta 1' seeds were treated with biological products Biokal $1\left(10 \mathrm{lt}^{-1}\right)$, Biokal $2\left(10 \mathrm{l} \mathrm{t}^{-1}\right)$, Biojodis $\left(2 \mathrm{lt}^{-1}\right)$ and Penergetic-p for roots $\left(100 \mathrm{ml} \mathrm{t}^{-1}\right)$, and with chemical treatment Maxim Star 025 FS (a.i. fludioksonil $18.75 \mathrm{~g} \mathrm{l}^{-1}$ and ciprokonazol $6.25 \mathrm{~g} \mathrm{l}^{-1}$ ) at a dose of $1.0 \mathrm{l} \mathrm{t}^{-1}$.

Treatment of organic winter wheat seeds with biological products increased their germination energy and germination. A significantly different variety of contamination with fungi was observed much greater when seeds were treated with Penergetic-p for roots. The greatest number of fungi was found in untreated seeds $\left(\mathrm{cfu} / \mathrm{g}-9.0 \times 10^{3}\right)$. Winter wheat seeds were not severely contaminated with Fusarium spp., Drechslera spp., Penicillium spp., however, they were seriously injured by Alternaria spp. Biojodis distinguished itself for the greatest efficiency protecting winter wheat seeds from fungi Fusarium spp. by $81.8 \%$, from Drechslera spp. by $100 \%$ and from Alternaria spp. by $30.9 \%$. Biological products Biokal 2, Penergetic-p for roots and Biokal 1 significantly decreased seed contamination with pathogens of Drechslera spp., however, these products proved to be inefficient in the case of seed contamination with fungi of Fusarium spp. Application of products Biokal 2 significantly decreased hypocotyls, Biokal 2 and Penergetic-p for roots decreased injury with root diseases. Biojodis protected wheat seeds completely from spreading root diseases.

Key words: organic farming, organic wheat seeds, germination energy, germination, contamination of fungi 